\title{
RECONCILIATION FROM THE TOP DOWN? GOVERNMENT INSTITUTIONS IN SOUTH AFRICA, RWANDA AND BURUNDI*
}

\author{
Cori Wielenga \\ Department of Political Sciences \\ University of Pretoria, South Africa
}

\section{Abstract}

National reconciliation has increasingly become an integral part of post-conflict recovery processes in Africa. What national reconciliation means, how it differs from interpersonal reconciliation and to what extent governments can facilitate reconciliation at all remains under debate. This article examines government institutions intended to facilitate national reconciliation processes in South Africa, Rwanda and Burundi. Rather than normatively prescribing what governments should be doing, this article seeks to examine what governments are doing as a starting point to understanding what national reconciliation is.

\section{Introduction}

In the past few decades, national reconciliation has become an integral part of post-conflict recovery processes (Bloomfield et al 2003; McGregor 2006; Broneus 2007; Sarkin 2008). Peace agreements, policies, laws and institutions have been formed in order to facilitate reconciliation within a nation-state (Abu-Nimer 2001; Murphy 2007). This article is particularly interested in institutions that have been

\footnotetext{
*This research had been made possible by support from the Social Science Research Council's African Peacebuilding Network research grant, with funds provided by Carnegie Corporation of New York.
} 
established by governments in Rwanda, Burundi and South Africa for the purpose of facilitating national reconciliation. It seeks to contribute to how we understand reconciliation on the national level in an African post-conflict context.

Although much has been written about institutions that facilitate reconciliation in South Africa (Boraine et al 1997; James and Van der Vijver 2007), Rwanda (Clark 2010; Clark 2011; Reyntjens 2013), and to a lesser degree, Burundi (Vandeginste 2012), far less comparative work has been done between these cases. This kind of comparative work has the potential to contribute to the conceptualisation of reconciliation, which is described time and again as a vague, amorphous and difficult term to work with (Bloomfield et al 2003; McGregor 2006; Bronéus 2007). Since it has started to be commonly used in political discourse (for example, in peace agreements, constitutions and policies), its meaning has become particularly contentious.

This article is going to use Crocker's (1999) 'spectrum of reconciliation' as a starting point, where he arranges the multitude of definitions for reconciliation along a spectrum from 'thin' or minimalist definitions to 'thick' or maximalist ones. 'Thin' definitions consider reconciliation as peaceful coexistence, or as Kriesberg (2001: 48) states "the process by which parties that have experienced an oppressive relationship or a destructive conflict with each other move to attain or to restore a relationship that they believe to be minimally acceptable". On the 'thick' end of reconciliation Lederach (1997: 26), describes, people on all sides of the conflict engaging each other as 'humans-inrelationship' and the restoring of relationships through healing and forgiveness. Bloomfield et al (2003: 19) describe reconciliation as a process rather than a spectrum, suggesting that reconciliation has three stages, namely, replacing fear by coexistence, building confidence and trust and developing empathy.

In this article, institutions that facilitate reconciliation refer to structures and mechanisms implemented by a national government to facilitate national reconciliation within a nation-state using state resources. 'National reconciliation', according to various scholars, is a term that emerged at the end of the Cold War, as countries in Latin America, the former Soviet Union and eastern Europe transitioned to liberal democracies (Wilson 2003; Forsythe 2011). Several scholars argue that national reconciliation is about building trust amongst citizens and between citizens and national institutions (Govier and Ver- 
woerd 2002; Bosire 2006; De Greiff 2008) or about nation-building and social cohesion (Wilson 2003) and is distinctly different from interpersonal reconciliation (Schaap 2003; Doxtader 2003).

Along with these scholars, this article emphasises that reconciliation on the interpersonal level (and, what Schaap calls 'theologically') means something distinctly different than on the national level and in the political sphere. A theological understanding would involve a community being restored through the admission of guilt and the offering of forgiveness, but Schaap (2003: 1) argues that "it is a political mistake to think of reconciliation in these terms, given the starkly opposed narratives in terms of which members of a divided polity typically make sense of past political violence".

However, in the case of South Africa in particular, this distinction has become blurred, as through Desmond Tutu in particular, institutions such as the Truth and Reconciliation Commission (TRC) used strongly theological language and the language of forgiveness (Van der Merwe 1999). This has been carried over into other African postconflict contexts where the language of peace agreements and other documents guiding the implementation of institutions that facilitate reconciliation echo that of South Africa (Curtis 2007). Wilson (2003) is critical of the blurring of the national and interpersonal, arguing that we cannot equate the national psyche with the individual psyche, and national healing with individual healing.

In an article in which he maps anthropological studies on national reconciliation, Wilson further criticises national reconciliation for being a tool used by governments for nation-building. He writes:

Whether in Latin America or South Africa or elsewhere, political and religious elites used a remarkably similar language of reconciliation, and their discourse was characterized by the following features: the construction of a new notion of the national self and psyche, the use of organic models of nation, the use of metaphors of illness and health and the creation of formulations of the common good which exclude retribution and encourage forgiveness (Wilson 2003: 370).

$\mathrm{He}$ is critical of the 'nationalist discourse' which accompanies national reconciliation and suggests that instead of understanding national reconciliation in terms of "the ideological terrain marked out by proponents of reconciliation, that is, the values, attitudes and dispositions underscoring moral and legal decision-making (i.e. whether or not it is 
morally right and good to forgive one's aggressors)" we should understand it as an exercise by governments to increase the legitimacy of their nationalist projects (Wilson 2003: 371).

This article attempts to forge a middle way between Wilson's critique and the 'ideological terrain' of proponents of reconciliation he describes by examining what government institutions that facilitate reconciliation actually do and suggesting a distinct position for national reconciliation within the reconciliation 'spectrum' that neither equates it with interpersonal reconciliation nor dismisses it as mere 'instrumentalisation'. When Wilson (2003: 383) critiques governments' interest in national reconciliation, he emphasises that it is "usually defined in the 'thick' sense of forgiveness". This is perhaps where the problem lies, in that where national reconciliation projects may not be able, for a multitude of reasons, some of which will be discussed in the conclusion of this article, to facilitate a 'thick' understanding of reconciliation, they may well have an important and necessary role to play on the 'thinner' end of the spectrum.

What remains difficult to ascertain is in what ways the institutions governments have established to facilitate reconciliation actually bring about reconciliation, and as various scholars have pointed out, measuring the progress of reconciliation remains a challenge (McGregor 2006; Bronéus 2007). In documents such as peace agreements or frameworks that describe the institutions that will facilitate national reconciliation, there is rarely attention given to how they will do this, or in what ways specific functions will contribute to particular aspects of a reconciliation process. ${ }^{1)}$ This article will not attempt to address this issue but will merely describe the institutions in order to explore what governments are doing with regard to national reconciliation. Whether or not these institutions do or do not actually facilitate reconciliation is the topic of another article.

Although this article touches on the debate as to whether national reconciliation is an instrumentalisation of the concept of reconciliation by governments to further their agenda of nation-building or not, this article will not discuss the nation-building literature per se. Being fully aware of the debate (see for example Connor 1972; Smith 1986; Linz 1993; Wilson 2003) as to whether nation-building is even a legitimate project, particularly in a post-colonial African context where people often hold citizenship in multiple countries and where a multiplicity of ethnicities coexist, this article is built on the assumption that 
nation-building is what governments do in a liberal democracy and that it currently forms a standard and necessary part of a post-conflict recovery process (Fukuyama 2004; Ottoway 2002).

From this starting point, the question this article seeks to answer is how we can understand national reconciliation based on what government institutions are doing to facilitate reconciliation through an examination of three case studies. In the case of Rwanda, this article will consider the gacaca trials and the National Unity and Reconciliation Commission, in the case of South Africa, the TRC, and in the case of Burundi, the ongoing debate around their proposed truth and reconciliation commission. There are numerous other smaller institutions that could be considered but due to space constraints, attention will only be given to these institutions and the activities that have directly emerged from them, such as attempts at redress and restitution, and the erection of memorials.

\section{South Africa}

During South Africa's apartheid, 18000 people were killed, and 80000 opponents of apartheid detained, with 6000 of these being tortured (Graybill 2004: 1116). Structural violence was present in every area of society, with policies and laws that led to the systematic dehumanising of millions of people on the basis of their race. The TRC was established to investigate human rights abuses committed between 1960 and 1994, and offer amnesty to individuals in exchange for their full disclosure about their past acts. The government implemented policies to assist in the redistribution of resources in various sectors such as in education, the health sector and the economy. In terms of memorialisation, various museums, commemoration days and monuments were erected and the history education syllabus was reworked. The government also launched an intensive media campaign through slogans and images that communicated 'unity in diversity'.

Conditional amnesty through a truth and reconciliation commission was chosen for pragmatic reasons, but also out of a desire to live out the precepts of the Constitution. In his book No Future without Forgiveness, Desmond Tutu describes how the negotiations prior to the transition to a new government resulted in economic power remaining in the hands of white South Africans. This and the fear of renewed violence meant that a retributive route would have been risky (Tutu 
2000: 23). But more than this, South Africa's interim constitution stated: "There is a need for understanding but not for revenge, a need for reparation but not for retaliation, a need for ubuntu but not for victimization". Graybill describes how forgiveness played a central role in the TRC process (Graybill 2004: 1118). The TRC drew from Christianity and the African philosophy of ubuntu; Tutu writes in his book about the possibility of both perpetrator and victim being rehumanised through the process of reconciliation. Although this approach led to moving encounters during the TRC proceedings, it has been criticised for blurring the boundaries between national and interpersonal reconciliation (Van der Merwe 1999).

Another major criticism of the TRC was that it failed to deal with the structural violence of apartheid and that economic power remained in the hands of white South Africans. In response to this, there has been an attempt at redress at several levels. Through policies such as affirmative action and Black Economic Empowerment (BEE) there has been an attempt at bringing about economic equity and redistributing the wealth in the country (Adam 1997). Radical reforms were brought about in the education and health sectors to address the institutional inequalities that existed (and to a large extent continue to exist) throughout the country (Barnes 2005). The redistribution of land through a contentious set of land reform policies has resulted in a very small percentage of land being transferred from white to black owners (Lahiff 2008).

Apart from attempts to bring about a more equitable social order in South Africa, several policies emerged during the establishment of the TRC to address reparations to victims of gross human rights violations during apartheid. Due to the limitations of the state, strict criteria were developed to specify who would benefit from these reparations, and some 20000 people were identified (Fernandez 1999, Ntlatleng 2012). However, to date, survivor support groups have been advocating for reparations to a broader group of South Africans. In studies undertaken with those who did benefit from the reparations, some expressed unhappiness that reparations were made by the state instead of by the perpetrators (Van der Merwe 2001: 187).

Apart from reparations, the TRC report recommended several initiatives towards memorialisation. Major monuments that were erected in South Africa, particularly under the influence of Thabo Mbeki, included Freedom Park in Pretoria, Robben Island in the Western 
Cape, the Apartheid Museum, the Women's Goal on Constitutional Hill in Johannesburg and the Hector Pietersen Memorial Museum in Soweto. Smaller memorials in city suburbs have also been erected in various parts of Cape Town, such as the Amy Biehl and Trojan Horse monuments and the District 6 area which remains an undeveloped piece of land. These memorials have been shrouded in controversy and criticised in the literature for being non-inclusive, not only in terms of who is (and is not) commemorated, but also for not involving the community in their conceptualisation. According to Saunders (2007) and Verbeeck (2007), this has meant that local people have had little ownership over monuments in their own communities.

Much of the work regarding community healing has been left to the churches and non-governmental organisations (NGOs) without the direct intervention of the government. South Africa has a very vibrant and active civil society that has a long history of reconciliation work in the country. However, civil society organisations have developed a contentious relationship with the South African government and have often taken on the role of mediating between communities and government, particularly in the rural areas (Habib and Kotze 2003: 247). Perhaps because CSOs are working in communities that had hoped for more from South Africa's transition and the TRC, they have developed an advocacy role, becoming the voice for a large group of marginalised South Africans.

As far as the discourse around reconciliation in South Africa is concerned, Van der Merwe (1999) describes how there have been movements in how reconciliation has been talked about over time (Bundy 2006 also traces similar changes in reconciliation discourse in South Africa with a focus on black intellectuals and editors). Initially, leaders such as Nelson Mandela and Desmond Tutu stressed the importance of forgiveness and 'ubuntu' which may have played an important role in ensuring South Africa's transition was peaceful. However, as the TRC proceedings unfolded it quickly became apparent that it was over-ambitious of the TRC to believe that it could contribute to interpersonal and community reconciliation. As a result the discourse began to change and emphasis was placed on the TRC as an agent to begin the reconciliation process and individuals and communities were encouraged to build on this foundation (Van der Merwe 1999). But, as Van der Merwe (1999: 538) argues, the TRC's 'flowery language' obscured the more pragmatic approach to recon- 
ciliation that was being operationalised and led to heightened expectations that were dashed as the limitations of what the TRC, and the government, were able (or unable) to do became apparent. Both in the South African media and in the literature it has become evident that over time, voices of anger, resentment and dissent have become louder amongst those who feel too little has changed and are calling for greater remorse on the part of white South Africans and a more equitable economy (Gobodo-Madikizela 2012; Bradbury 2012; VillaVicencia 2013). This brings to attention the difference in understanding of what reconciliation means between elite-actors and individuals and the importance of distinguishing between different kinds of reconciliation taking place at different levels and being initiated by different actors.

\section{Rwanda}

In 1994, almost a million Tutsi and moderate Hutu were killed in Rwanda during the three month government-led genocide. Prior to this, in the post-colonial period there were repeated incidences of violent ethnic conflict where thousands of Rwandans were killed and many more fled the country. The genocide in 1994 ended when a military group of mostly Tutsi exiles, the Rwandan Patriotic Front (RPF), overthrew the Rwandan government and took power in the country. But by this time, the country had been stripped of all resources, the government coffers were empty and almost every Rwandan was either internally displaced or had fled the country. There was no judicial system left in place and the RPF had to rebuild the country from scratch while hundreds of thousands of people accused of genocide crowded inadequate jails (Prunier 1995).

The response to this judicial crisis was the establishment of the gacaca courts, which drew from a traditional practice of restorative justice practiced in Rwanda before colonialism. A great deal of criticism has been directed at the gacaca system, including its insistence on only dealing with crimes committed by the genocidaires and not those by the RPF (Graybill 2004), its compromise of internationally agreedupon human rights and criminal law standards (Uvin in Kinzer 2008), its inability to provide support for those who were retraumatised through testifying (Brounéus 2008), the danger of it being seen as victor's justice (Mamdani 2001) and its eventual movement away from a restorative justice approach (Wielenga and Harris 2011). 
Significantly, though, the gacaca trials were a uniquely indigenous response in ensuring the accountability of perpetrators in mass violence through trying large numbers of people in a relatively short space of time (Reyntjens 2013 discusses the controversy around the exact numbers but it remains the highest number of individuals tried for a single mass atrocity). By-and-large, many of its critics have perhaps grudgingly also supported gacaca as a necessary response to the challenge that faced that country. Uvin, for example, states that although international legal standards were 'profoundly compromised', "some compromise is simply unavoidable" because "criminal law standards were not designed to deal with the challenges faced when massive numbers of people - victims and perpetrators of crime have to live together again side by side in extremely poor and divided countries" and that the gacaca courts, in actuality, do "respect the spirit of international human rights law" (in Kinzer 2008: 258).

Although Rwanda has not adopted South Africa's approach of amnesty, the language of forgiveness was prominent in the gacaca trials. Article 54 of the gacaca law states that "any person who has pleaded guilty, has shown repentance and asked for forgiveness" shall serve a reduced sentence (Penal Reform International 2007: 10). In his first genocide commemoration speech in 2001, President Kagame praised those who had sought forgiveness, further stating that "asking for forgiveness and forgiving go together, and call for courage, which may sometimes appear to be impossible" (Zorbas 2009: 137). But this language of forgiveness has not carried over into the other major government institution intended to facilitate reconciliation, namely, the National Unity and Reconciliation Commission (NURC).

The NURC, in their documentation, describe reconciliation as "a consensus practice of citizens who have common nationality, who share the same culture and have equal rights; citizens characterized by trust, tolerance, mutual respect, equality, complementary roles/ interdependence, truth, and healing of one another's wounds inflicted by our history, with the objectives of laying a foundation for sustainable development" (NURC 2007: 6). This definition seems to lie more on the 'thin' end of the reconciliation spectrum, and emphasises trust between citizens rather than forgiveness.

Where South Africa brought together forgiveness, truth-telling and amnesty, Rwanda emphasised individual accountability for crimes committed through the gacaca trials (Graybill 2004). Due to the 
overcrowding of prisons amongst other things, punishment for those who confessed (and expressed remorse and asked for forgiveness) has been in the form of Travaux d'Interêt Général (TIG), a form of community service. TIGistes, as they are commonly referred to, go through a training and reintegration program and then undertake work to rebuild houses and provide other community services (Penal Reform International 2007). According to a Penal Reform International report, TIGistes are organised into work camps and rebuild houses, quarry stone for the road and reinforce the terrace system. In total, the number of TIGistes is expected to be in the area of 300000 to 500 000. Penal Reform International argues that from the perspective of TIGistes and their families, it may be difficult to distinguish between this form of 'community service' and a prison sentence, as TIGistes remain in the camps, apart from their families, and engage in hard labour.

With the establishment of the gacaca courts, it was the intention to implement a government initiated Compensation Fund to assist survivors in obtaining reparations, but to date this fund has not been established. A Bill was passed in 1998 to establish the Fonds d'Assistance pour les Rescapés du Genocide (FARG) as the government's reparations mechanism and is by law the only organisation that can make a claim for reparations on behalf of victims (SURF 2012). Penal Reform International describes how FARG was repealed and replaced by a new Bill in 2007 that clearly states that it is not offering compensation: "Support and help programmes for the benefit of the victims shall not constitute compensation. Rather they offer assistance that is owed to the victims in order to help them to overcome the serious difficulties they are experiencing as a result of the genocide and other crimes against humanity" (Penal Reform International 2007: 96). This fund is contentious in Rwanda due to the debate of who 'counts' as a survivor, and with many survivors complaining that they have not received support (SURF 2012).

The issue of who is a survivor, and whose losses need to be commemorated is reflected in the many memorial sights in Rwanda. Some of the significant memorial sights include the Kigali Genocide Memorial Site, the Murambi Genocide Prevention Centre, the Ntarama national memorial site, the Bisesero site, and the Nyamata national memory site where bones have been preserved and are displayed. The month of April is annually a time to commemorate and remember 
the genocide. Memorial sights and the April commemorations have been contentious in Rwanda, with criticisms including that victims are retraumatised through the raw images and have not been allowed their own ways of remembering and, in a completely different vein that the memorialisations are one-sided and give no attention to the loss Hutus experienced during the civil war (Ibrek 2010: 342).

It is in this context that the NURC, one of the first permanent, constitutionally protected institutions in Africa with the specific mandate to facilitate national reconciliation, is working. The work of the NURC which is to "prepare and coordinate the national programme for the promotion of national unity and reconciliation" through education, research, publications, and community dialogue (IJR 2005:5) has been the object of much criticism. Particularly, it has been criticised for perpetuating the government's top-down approach to bringing about unity through denying ethnic identities (Buckley-Zistel 2006; Clark 2010; Schuberth 2013).

The NURC has been responsible for implementing ingando solidarity camps which were first intended for the reintegration of excombatants but has now expanded to include teachers, students, politicians and community leaders (Mgbako 2005). During the time spent there (anywhere between three weeks and two months) participants are taught about Rwanda's history, why the genocide happened, their new united identity and the way forward for Rwanda. Many researchers have been critical of ingando, describing it as yet another way the Rwandan government enforces a particular ideology on all Rwandans (Mgbako 2005).

But the NURC's primary area of intervention is on the community level through district forums and community dialogue, which has been sparsely discussed in the literature. These district forums coordinate the reconciliation related activities of community leaders, local and international NGOs and government. Although some may see this as another form of control on the part of government, those involved in the district forums have described it as a helpful mechanism to coordinate work in the community and have found forum meetings a space for open and critical dialogue. ${ }^{2}$

Much of the criticism concerning the NURC and gacaca has been from the perspective of outsiders who are assessing these institutions from a particular understanding of criminal justice or a particular understanding of what community participation in a democracy should 
look like but far less research has been undertaken to understand how Rwandans themselves have experienced them.

An exception to this is the research of Zorbas who studied the ways in which reconciliation was understood in two communities in Rwanda. His findings show that where initially members of the community used terms like 'forgiveness', echoing, according to Zorbas, official slogans, as he built stronger relationships with those interviewed, they used 'thinner' language to describe reconciliation, such as 'being civil to one another' (2009: 134). He comes to the conclusion that "my respondents resented the government usurping the right of victims to be the sole, legitimate granters of forgiveness" (2009: 142). They resented, he argues, the institutionalisation of forgiveness which typified the approach to reconciliation during the gacaca trials. These findings contribute to the discussion of the distinct differences that exist between national and interpersonal reconciliation and what the position of government institutions that attempt to facilitate national reconciliation is. The NURC, in its conscious movement away from the language of forgiveness over the past few years, at least on paper, seems to recognise its limitations in its involvement on the interpersonal level.

\section{Burundi}

Since its independence in 1962, Burundi has been fraught with violent conflict. The root of this conflict has been a complex interplay between ethnic and political factors that has resulted in the death of hundreds of thousands of people, with as many fleeing to other countries (Nindorera 2003: 4). In 1998, peace negotiations began in Arusha, Tanzania, which eventually led to democratic elections in 2005 . These negotiations outlined the way forward for Burundi in terms of transitional justice and reconciliation.

The Peace and Reconciliation Agreement that was signed in 2000 included the resolution for a national Truth and Reconciliation Commission (TRC), an International Judicial Commission of Inquiry (IJCl) and the possibility of an international criminal tribunal. The TRC was intended to take two years to conduct its work and would have been completed during the period the transitional government was in office. To date neither the TRC nor IJCl have been implemented. A Technical Commission was appointed by the government to draft a 
law on the creation, mandate, composition, organisation and functioning of the TRC. National consultations were held in 2009 both to ascertain what Burundians wanted from the transitional justice process and to involve Burundians in the process (CENAP 2010).

The historical and more recent violent conflict in Burundi is a complex intersection of ethnic and political conflict (Lemarchand 1970; Prunier 1994). During the civil war, between 1993 and 2005, the conflict was firmly narrated in ethnic terms. However, there has been a shift occurring in the conflict in Burundi over the past few years, from ethnic to political. One of the significant reasons for this shift is the ethnic quota system that Burundi has implemented as a result of the negotiated agreement. According to Vandeginste, "It is generally recognized that this process of engineering of ethnicity has, so far, been highly successful and has strongly reduced ethnopolitical tension. Today's main political divide is no longer ethnic" (Vandeginste 2012).

The conflict today is between competing political parties, particularly the ruling party, the Conseil National Pour la Défense de la Démocratie-Forces pour la Défense de la Démocratie (CNDD-FDD) and the Forces nationales de libération (FNL), which are both described as being 'Hutu' parties. Since the 2010 elections, political tensions have been rising, with some suggesting that the political space is increasingly closing (HRW 2010). There has been an increase in politically and criminally motivated violence. Some opposition leaders have fled the country, others have been arrested and media and civil society groups have been harassed (Vandeginste 2012). Until now, the government has ascribed this violence to criminal activities, but others have argued that it is political violence between the FNL and CNDD-FDD.

Amidst this low level conflict, the implementation of a TRC or other transitional justice mechanisms has become a contentious issue. The question remains whether the political environment in Burundi is too fragile to support a national reconciliation facilitated through, for example, a truth and reconciliation commission or inquiries. Although it has been assumed by some that the resistance to implementing transitional justice mechanisms in Burundi are as a result of political actors not wanting to take responsibility for the crimes they have committed (Human Rights Watch 2009; Vandeginste 2010), several other reasons have emerged, such as the fragile political environment, the fragile relationship between political (local) actors and conflict between 
external and local actors (Rubli 2013). Rubli suggests that where local actors are interested in a more 'reconciliatory' form of justice, external actors are interested in a criminal/legal mechanism that emphasises retributive justice.

Although this is most likely a polarisation of the reality, Rubli's (2013) discussion regarding the different ways in which local and external actors perceive reconciliation and transitional justice (which is currently central to the question of national reconciliation in Burundi) is relevant here. She argues that transitional justice is understood in narrow terms by the international community, and is confined to a liberal peace-building model which emphasises humanitarian law, international criminal law and human rights law whereas the political party leaders she interviewed in Burundi argued for a more 'reconciliatory' interpretation of justice (Rubli 2013: 15). Although few official government documents exist describing the government position on reconciliation, according to a political party memorandum on transitional justice released by the ruling party, CNDD-FDD, it is clear that for them that where a truth and reconciliation commission facilitates reconciliation, a criminal tribunal leads to 'repression' (Rubli 2013: 10). During her interviews, CNDD-FDD leaders spoke of how significant progress in ethnic relations has already occurred and that a tribunal which emphasised ethnic conflict that occurred in the past might reignite ethnic divisions. "Justice promoted by the tribunal would risk reframing the conflict once more in ethnic terms by opposing (Hutu) perpetrators to (Tutsi) victims" (Rubli 2013: 11).

In the same document it is stated, that "if the perpetrator of the crime has acknowledged the facts and asked for forgiveness, and the victim has granted it, then the CNDD-FDD would consider judicial accountability through the tribunal to be unnecessary" (Rubli 2013: 11). This echoes the kind of amnesty for truth trade that was evident in South Africa, and echoes the gacaca law that states that if the perpetrator acknowledged what they have done, expresses remorse and asks for forgiveness, they receive a reduced sentence. Significantly, in fieldwork in rural Burundi, Ingelaere and Kohlhagen (2012: 52) found that ordinary Burundians were not necessarily interested in truth-seeking or perpetrators being held accountable for their crimes, with several saying that they should 'not dig up what has been buried'. Instead Ingelaere and Kohlhagen found their respondents expressing was a desire for a 'change of heart'. Ingelaere and Kohlhagen explain what 
this means in the Burundian context in some depth, but for the purpose of this article it may be suffice to say that it suggested a relatively thick understanding of reconciliation.

Although this is an area of research that needs to be explored further, a significant difference between South Africa, Rwanda and Burundi is that where the institutions that facilitate reconciliation were largely shaped by local actors in the former two cases, in the case of Burundi, as Rubli (2013) describes, external actors play a significant, and arguably hindering role. Establishing institutions that facilitate reconciliation in Burundi are strongly influenced in particular by donor countries and organisations such as the European Union (EU) and United Nations (UN). There is little evidence that the Burundian government has taken a leading role in forging its own national reconciliation agenda.

The few existing documents that do describe the government's interest in reconciliation emphasise a revival of traditional Burundian values and practices. Nindorera (2003: 18) describes that during the peace talks, particular attention was given to the resurrection of cultural values to assist in the peace and reconciliation process in Burundi. These included ibanga or the sense of confidentiality/secret and responsibility, ubupfasoni or dignity and respect, and ubuntu or humanity. The Burundian governments Vision 2025 document (2008: 29) adds to this the importance of promoting cultural identity as a means of bringing about social cohesion, such as 'ubuntu, tolerance, respect for the other, sharing', Burundian dance, folktales, literature, poetry and drama.

In addition, there has also been the suggestion to restore the traditional bashingantahe councils, which historically consisted of wise elders who would play a central role in maintaining the values of a community and facilitating community-level dispute resolution. However, as of 2010, they have been formally excluded from Burundian legislation by the government (Ingelaere and Kohlhagen 2012). The initial revival of the council was encouraged by external actors (Nindorera 2003) but the current government has consistently resisted this traditional institution, primarily because it had become so strongly associated with first the monarchy and then the post-independence one-party state (Ingelaere and Kohlhagen 2012: 44). Based on their fieldwork in rural Burundi, Ingelaere and Kohlhagen have found that although the bashingantahe remain the ones communities turn to in 
order to resolve their disputes, in many cases, they were unable to actually bring about a resolution and were sometimes accused of being biased or corrupt. Interestingly, they found that the principles of bushingantahe - which Nindorera (2003) compares variously to 'ubuntu' and 'integrity' - held greater sway in communities than the council of the bashingantahe and they see this as a potential way forward in terms of rehabilitating this institution.

One visible marker of the government's involvement in national reconciliation has been the erection of a national monument dedicated to all victims of violence in the town of Gitega which is in the centre of the country. But Vanderlick and Batungwayo (2012: 15) in an extensive survey of memorials and memory work in Burundi, describe how there are countless smaller memorials have been created largely through a variety of survivor groups which has resulted in commemoration and memorialisation in Burundi as being fragmented, often along conflict lines.

On paper, the government has expressed its approach to national reconciliation in distinctly different ways from that of Rwanda. Where in Rwanda there has been attempt at national reconciliation through 'a consensus practice of citizens' which involves banning ethnicity to create a united Rwandan identity, in Burundi the emphasis seems to be the 'regional blending of ethnic groups'.3) This is reflected in the policy of ethnic quotas in the government and military.

But to date, the government has failed to put forward a clear agenda for national reconciliation, as it struggles to maintain the fragile peace it has won and it is in a deadlock with international actors concerning the way forward for transitional justice. The case of Burundi will be an interesting one to follow in terms of what the government says about reconciliation and what eventually unfolds.

\section{Discussion and conclusion}

Reconciliation is a concept that has been understood to mean different things in different contexts by different actors. This article is an attempt to contribute to how national reconciliation is conceptualised by looking at government institutions that facilitate reconciliation in South Africa, Rwanda and Burundi. In all three case studies, governments may have expressed particular ideals in their discourse which are not necessarily mirrored in the institutions intended to facilitate 
reconciliation themselves. Further, in each, how reconciliation is conceptualised and approached has changed over time. But perhaps of greatest significance, the limitations of government institutions to facilitate interpersonal healing and reconciliation have been evident. As Wilson (2003) and Van der Merwe (1999) have argued, the official discourse tends to be 'thick', 'flowery', and with regular references to forgiveness. Yet in actuality, these institutions are unable to facilitate this kind of 'thick' reconciliation and at best are contributing to 'peaceful coexistence'.

Returning to Wilson's (2003) argument that was referred to in the introduction, that governments instrumentalise reconciliation for the purpose of nation-building, Buckley-Zistel (2006) similarly argues in the case of Rwanda that the government is interested in 'unity without reconciliation'. Certainly a major feature of national reconciliation efforts in South Africa has been to create a united South African identity, evident, for example, in the slogan 'unity in diversity'. Rwanda's reconciliation discourse has focused on denying ethnic identity in order to embrace a united 'Rwandanness'. Although the Burundian government has taken a different approach than Rwanda by accepting the existence of diverse ethnicities, its emphasis on reconciliation through shared cultural values and traditions echoes the Rwandan and South African attempts at national reconciliation through creating a shared sense of identity.

Drawing from this discussion, this article contends that the concerns of governments are related to creating a shared identity which will allow for a shared future without direct violence, rather than healing and restoring broken relationships. This would be in line with what Schaap (2003: 1) argues reconciliation is about in political terms: "the ability of a conflicting group of people to collectively imagine a shared identity and future in a nation state". While some have judged this 'thinner' approach by governments to be problematic, I argue that it is primarily problematic because governments are expected to be involved in interpersonal reconciliation when this is an unrealistic function for a government to fulfil. Rather than insisting that governments adopt a 'thicker' approach to their reconciliation work, it may be more helpful to create clearer distinctions between national reconciliation by government institutions and interpersonal reconciliation by other actors.

This would allow for the development of clearer policy frameworks and guidelines related to government institutions that facilitate 
national reconciliation. When peace agreements, government documents and policy frameworks refer to reconciliation in broad, vague terms, and the official reconciliation discourse becomes 'flowery', it is not surprising that implementation is undermined. Instead, if reconciliation is more carefully defined in the political sphere as being about nation-building (through, amongst other things, the creation of a shared identity and a shared vision for the future) and facilitating peaceful coexistence (rather than interpersonal reconciliation) policy frameworks and guidelines can become more specific and targeted. If we can begin to conceptualise reconciliation differently in these different contexts, we can begin to create more realistic expectations and more helpful systems of holding governments accountable to what they are able to achieve within their limited capacity.

\section{Endnotes}

1. I discuss this at length in a working paper titled: "Mediated power sharing agreements, reconciliation and transitional justice: The cases of Liberia, Burundi and the Democratic Republic of Congo" that is to appear in the Mediation Arguments working paper series later in 2014.

2. These findings are based on fieldwork undertaken in Rwanda between 2009 and 2014, which built on fieldwork undertaken for my PhD between 2005 and 2009. Although this fieldwork does not play a prominent role in this article, I refer to it here as the literature does not refer to NURC's district forums.

3. This is quoted from the Vision 2025 document that describes the Burundian governments' vision for the country.

\section{Bibliography}

Abu-nimer, M (2001), Reconciliation, justice and coexistence: Theory and practice. Oxford: Lexington books.

Adam, K (1997), "The politics of redress: South African style Affirmative Action", The Journal of Modern African Studies, Vol 35, No 2, pp 231-249.

Barnes, T (2005), "Changing discourses and meanings of redress in South African Higher Education 1994-2004", Centre for Civil Society Research Report, No 38, pp 1-22.

Bloomfield, D, Barnes, T and L Huyse (2003), Reconciliation after violent conflict: A handbook. Stockholm: IDEA International.

Boraine, A, Levy, J and R Scheffer (1997), Dealing with the past: Truth and 
reconciliation in South Africa. Cape Town: IDASA.

Bosire, L (2006), "Overpromised, underdelivered: Transitional Justice in SubSaharan Africa", International Center for Transitional Justice Occasional Paper Series.

Bradbury, J (2012), "Narrative possibilities of the past for the future", Peace and Conflict: Journal of Peace Psychology, Vol 18, No 3, pp 341-350.

Brounéus, K (2007), Reconciliation and development. Occasional Paper 37. Berlin, Friedrich-Ebert-Stiftung.

Brounéus, K (2008), "Truth Telling as Talking Cure? Insecurity and Retraumatization in the Rwandan Gacaca Courts", Security Dialogue, Vol 39, No 1, pp 55-76.

Buckley-Zistel, S (2006), "Dividing and uniting: The use of citizenship discourses in conflict and reconciliation in Rwanda", Global Society, Vol 20, No 1, pp 101-113.

Bundy, C (2007), "New nation, new history? Constructing the past in postapartheid South Africa", in Stolten, H E (ed), History making and present day politics: The meaning of collective memory in South Africa. Uppsula: The Nordic Africa Institute, pp 73-97.

Centre d'Alerte et de Prévention des Conflits (Cenap) (2010), "Report: Major challenges and potential points of leverage in the drive to encourage political parties in Burundi to formulate policies and carry out programs". Bujumbura, Burundi.

Clark, J N (2010), "National unity and reconciliation in Rwanda: A flawed approach?", Journal of Contemporary African Studies, Vol 28, No 2, pp 137154.

Clark, P (2011), The Gacaca Courts, Post-Genocide Justice and Reconciliation in Rwanda. Cambridge: Cambridge University Press.

Connor, W (1972), "Nation-Building or Nation-Destroying?", World Politics, Vol 24, No 3, pp 319-355.

Crocker, D (1999), "Reckoning with Past Wrongs: A Normative Framework", Ethics and International Affairs, Vol 13, No 1, pp 60-61.

Curtis D (2007), "South Africa: Exporting Peace to the Great Lakes Region", in Adedeji, A and C Landsberg (eds), South Africa in Africa: The postApartheid era. Scottsville: University of KwaZulu Natal Press.

De Greiff, P (2008), "The role of apologies in national reconciliation processes: On making trustworthy institutions trusted", in Gibney, M, Howard-Hassmann, R E, Coicaud, J M and N Steiner (eds), The Age of Apology. New York: Oxford University Press.

Doxtader, E (2003), "Reconciliation — a rhetorical concept/ion", Quarterly Journal of Speech, Vol 89, No 4, pp 267-292. 
Dwyer, S (1999), "Reconciliation for Realists", Ethics and International Affairs, Vol 13, No 1, pp 81-98.

Fernandez, L (1999), "Reparations policy in South Africa for victims of apartheid", Law, Democracy and Development, Vol 3, No 2, pp 209-222.

Forsythe, D P (2011), "Forum: Transitional Justice: The Quest for Theory to Inform Policy", International Studies Review, Vol 13, No 1, pp 554-578.

Fukuyama, F (2004), State-Building: Governance and World Order in the 21st century. New York: Cornell University Press.

Gobodo-Madikizela, P (2012), "Remembering the past: Nostalgia, traumatic memory, and the legacy of Apartheid", Peace and conflict: Journal of Peace Psychology, Vol 18, No 3, pp 253-269.

Govier, T and W Verwoerd (2002), "Trust and the Problem of National Reconciliation", Philosophy of the Social Sciences, Vol 32, No 2, pp 178-205.

Graybill, L (2004), "Pardon, punishment, and amnesia", Third World Quarterly, Vol 25, No 6, pp 1117-1130.

Habib, A and H Kotze (2003), "Civil society, governance and development in an era of globalization: The South African case", in Guy C Z Mhone and O Edigheji (eds), Governance in the New South Africa: The challenges of globalisation. Claremont: Juta and Company Ltd, pp 246-269.

Human Rights Watch. (2010), Closing doors? The narrowing of democratic space in Burundi.

Huyse, L (2013), Transitional Justice after war and dictatorship: Learning from European experiences (1945-2010). Final Report. Centre for Historical Research and Documentation on War and Contemporary Society.

Ibrek, R (2010), "The politics of mourning: Survivor contributions to memorials in post- genocide Rwanda", Memory Studies, Vol 3, No 4, pp 330-343.

Ingelaere, B and D Kohlhagen, D (2012), "Situating social imaginaries in transitional justice: The Bushingantahe in Burundi", International Journal of Transitional Justice, Vol 60, No 1, pp 40-59.

Institute for Justice and Reconciliation (2005), Evaluation and impact assessment of the National Unity and Reconciliation Commission (NURC): Final report December (Available at: http://www.nurc.gov.rw/documents/researches/ Impact_Assessment_of_NURC_full_report.pdf).

James, W and L Van der Vijver (2000), After the TRC. Cape Town: The Rustica Press.

Kinzer, S (2008). A thousand hills: Rwanda's rebirth and the man who dreamed it. New Jersey: Wiley.

Kriesberg, L (2001), "Changing forms of coexistence", in Abu-Nimer, M (ed), Reconciliation, justice, and coexistence: Theory and practice. Lanham: Lexington Books. 
Lahiff, E (2008), Land Reform in South Africa: A status report. Programme for Land and Agrarian Studies. Research Report 38. University of the Western Cape.

Lederach, J (1997), Building peace: Sustainable reconciliation in divided societies. Washington, DC: United States Institute of Peace Press.

Lemarchand, R (1970), Rwanda and Burundi. New York: Praeger Publishers.

Linz, J J (1993), "Nations, States and Human Rights: State building and nationbuilding", European Review, Vol 1, No 4, pp 355-369.

Mamdani, M (1996), Citizen and subject: Contemporary Africa and the legacy of late colonialism. Princeton: Princeton University Press.

Mamdani, M (2001), When victims become killers: Colonialism, nativism and the genocide in Rwanda. Princeton: Princeton University Press.

McGregor, L (2006), "Reconciliation: I Know It When I see It", Contemporary Justice Review, Vol 9, No 2, pp 155-174.

Mgbako, C (2005), "Ingando solidarity camps", Harvard Human Rights Journal, Vol 18, No 1, pp 202-220.

Minow, M (1998), Between vengeance and forgiveness: Facing history after genocide and mass violence. Boston: Beacon Press.

Murphy, C (2007), "Political Reconciliation, the Rule of Law, and Genocide", The European Legacy, Vol 12, No 7, pp 853-865.

National Unity and Reconciliation Commission (2007), The National Policy on Unity and Reconciliation. Kigali, Rwanda.

Nindorera, A (2003), Ubushingantahe as a base for political transformation in Burundi. Boston Consortium on Gender, Security and Human Rights. Working Paper No 102.

Ntlatleng, B (2012), "Justice on track with its work to assist apartheid victims", Justice Today, Vol 1, No 1 (Available at: http://www.justice.gov.za/docs/articles/ (2012)-trc- reparation.html).

Ottoway, M (2002), "Nation-building", Foreign Policy, Vol 132, No 1, pp 16-24.

Prunier, G (1995), The Rwanda crises: History of a genocide. London: Hurst and Company.

Reyntjens, F (2013), Political governance in post-genocide Rwanda. Cambridge: Cambridge University Press.

Rubli, S (2013), "Remaking the social world: The politics of transitional justice in Burundi", Africa Spectrum, Vol 48, No 1, pp 3-24.

Sarkin, J (2008), "Achieving Reconciliation in Divided Societies: Comparing the Approaches in Timor-Leste, South Africa and Rwanda", Yale Journal of International Affairs, Vol 3, No 2, pp 1-25.

Saunders, C (2007), "The transformation of heritage in the new South Africa", in Stolten, H E (ed), History making and present day politics: The meaning of collective memory in South Africa. Uppsula: The Nordic Africa Institute, 
pp 183-195.

Schaap, A (2003), The time of reconciliation and the space of politics. The University of Melbourne, Australia Working Paper 2003/8 Centre for Applied Philosophy and Public Ethics (CAPPE).

Schuberth, M (2013), "The politics of knowledge production in post-genocide Rwanda", Strategic Review for Southern Africa, Vol 35, No 1, pp 78-92.

Smith, A (1986), "State-Making and Nation-Building", in Hall, J (ed), States in History. Oxford: Basil Blackwell, pp 228-263.

SURF and Redress. (2012), No justice without reparation: Recommendations for reparation for survivors of the 1994 genocide. Discussion Paper.

Tutu, D (2000), No future without forgiveness. New York: Random House.

Van der Merwe, H (1999), Reconciliation commission and community reconciliation: An analysis of competing strategies and conceptualizations. A dissertation submitted in partial fulfillment of the requirements of the degree of $\mathrm{PhD}$ at George Mason University.

Van der Merwe, $\mathrm{H}$ (2001), "Reconciliation and justice in South Africa: Lessons from the TRC's community interventions", in Abu-Nimer, M (ed), Reconciliation, justice and co-existence. Oxford: Lexington Books, pp 187-208.

Vandeginste, S (2009), "Transitional justice for Burundi: A long and winding road", in Ambos, K, Large, J and M Wierda (eds), Building a future on peace and justice. Heidelberg: Springer Berlin, pp 393-422.

Vandeginste, S (2012), "Burundi's Truth and Reconciliation Commission: How to shed light on the past while standing in the dark shadow of politics", The International Journal of Transitional Justice, Vol 6, No 3, pp 1-11.

Vanderlick, B and A Batungywanayo (2012), Lieux de mémoire, commemorative initiatives and memorials to Burundi's conflicts: Invisible and permanent memories. Impunity Watch Perspectives Series: Research Report.

Villa-Vicenio, C (2013), "A moratorium on 'reconciliation'?", SA Reconciliation Barometer newsletter, Institute for Justice and Reconciliation (Available at: http://reconciliationbarometer.org/2013/03/lastest-newsletter-released/).

Wielenga, C and G Harris (2011), "Building peace and security after genocide: The contribution of the gacaca courts of Rwanda", African Security Review, Vol 20, No 1, pp 15-25.

Wilson, R A (2001), The politics of truth and reconciliation in South Africa: Legitimizing the Post-Apartheid State. Cambridge: Cambridge University Press, pp 13-18.

Zorbas, E (2009), "What does reconciliation after genocide mean? Public transcripts and hidden transcripts in post-genocide Rwanda", Journal of Genocide Research, Vol 11, No 1, pp 127-147. 